J. M. SYNGE: A BIBLIOGRAPHY OF CRITICISM 
By the same author

The Social and Cultural Setting of the 1890s

John Galsworthy the Dramatist

Comedy and Tragedy

Sean O'Casey: A Bibliography of Criticism

A Bibliography of Modern Irish Drama 1899-1970

Dissertations on Anglo-Irish Drama: A Bibliography of Studies 1870-1970

The Sting and the Twinkle: Conversations with Sean O'Casey (co-editor with John O'Riordan) 


\title{
J. M. SYNGE
}

\section{A Bibliography of Criticism}

\author{
E. H. Mikhail \\ Professor of English Literature \\ University of Lethbridge, Canada
}

\author{
Foreword by \\ Robin Skelton \\ Professor of English \\ University of Victoria, British Columbia
}

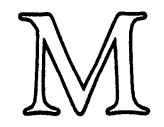


(C) E. H. Mikhail 1975

Softcover reprint of the hardcover 1st edition 1975

All rights reserved. No part of this publication may be reproduced or transmitted, in any form or by any means, without permission.

First published 1975 by

THE MACMILLAN PRESS LTD

London and Basingstoke

Associated companies in New York

Dublin Melbourne Johannesburg and Madras

SBN 333168291

ISBN 978-1-349-02278-6 ISBN 978-1-349-02276-2 (eBook)

DOI 10.1007/978-1-349-02276-2 
To my Wife 


\section{Contents}

Foreword by Robin Skelton

Preface

ix

xiii

BIBLIOGRAPHIES

BOOKS BY J. M. SYNGE AND THEIR REVIEWS 9

In the Shadow of the Glen 9

The Shadow of the Glen and Riders to the Sea 9

The Well of the Saints 9

The Aran Islands 9

The Playboy of the Western World 9

The Tinker's Wedding 10

Poems and Translations 10

Deirdre of the Sorrows 10

The Works of John M. Synge 10

Some Unpublished Letters and Documents of
J. M. Synge

The Autobiography of J. M. Synge $\quad 11$

Collected Works 11

Some Letters of John M. Synge to Lady Gregory and W. B. Yeats

Letters to Molly

The Synge Manuscripts in the Library of Trinity

College Dublin

Some Sonnets from 'Laura in Death'

J. M. Synge to Lady Gregory and W. B. Yeats

My Wallet of Photographs

CRITICISM ON J. M. SYNGE

(a) Books 


\section{Contents}

(b) Periodicals 69

(c) Reviews of Play Productions 108

The Shadow of the Glen 108

Riders to the Sea 117

The Well of the Saints 125

The Playboy of the Western World 133

The Tinker's Wedding 183

Deirdre of the Sorrows 186

(d) Unpublished Material 191

(e) Recordings 198

(f) Background 199

Index of Works 201

Index of Authors $\quad 202$ 


\section{Foreword by Robin Skelton}

The amount of information given in this volume is a clear indication of the interest that the work of J. M. Synge has aroused over the years. Even a brief scrutiny of the titles of the various articles and critical works reveals the way in which Synge's work has aroused an extraordinary variety of reactions. Synge, indeed, is a Shakespearean figure in that he, like Shakespeare, had been used in the service of a wide variety of causes. We can find critics who use him to maintain the importance of Irish Nationalism; we can find others who use him as an exemplar of the European Sensibility. He has been viewed as primarily a satirist, as essentially a romantic, as a thoroughgoing realist, and as the most subtle of symbolists. The Aran Islands has been lauded as an exact portrayal of an important aspect of Irish life and tradition, and as a deeply personal piece of myth-making. The Playboy of the Western World has aroused almost as much controversy as Hamlet, and a good deal more political disturbance.

It is not only the work but also the personality of Synge which present problems of this kind. Here again we find differing views. How can we reconcile the tough-minded, harsh-tongued Synge of some of the more 'brutal' poems with the anxious, jealous, neurotic writer of the letters to Molly? How can we reconcile the author of the Letter to a Hedge Schoolmaster with the man who adored the Irish language? How can we, even, reconcile the anarchist (or at least socialist) opinions implied by many essays, with those of others which reveal a nostalgia for the days of the 'Big House' and how bring together the anarchism and the elitism?

The problem of seeing Synge clear and of seeing him whole has been intensified by the accidents of history. Until the nineteen-sixties, when the Oxford University Press edition of 


\section{Foreword}

his work began to come off the presses, we had no texts of half his poems, and only a hint or two about many of his early essays into drama. The Greene and Stevens biography emerged fifty years after the writer's death, and this has been followed by a number of books in which additional biographical information has been given, as well as several collections of letters many of which were unknown to the biographers. As a consequence of this, much relating to Synge remains to be discussed. His political views have only been touched upon gingerly, possibly because it is difficult to fit him into any acceptable party or category. His lifelong (almost) obsession with the Muse-like figure of the inspiring and shaping woman has not yet received due attention. (One should recall here that Petrarch first saw Laura in a green gown, that Synge called one of his earliest lady friends in Paris, La Robe Verte, and translated Petrarch towards the end of his life, and that green is the colour of Ireland.) Much, indeed, remains to ponder over and to comment upon, but no fresh investigation can be begun without a close examination of all that has been said so far.

It is here that this book is of such enormous value. It directs us, with clarity and precision, to all the most significant and symptomatic reactions to the work of Synge. It enables us to begin to see how the criticism of Synge has been distorted by political enthusiasms, by personal prejudice, and by the changing perspectives of history. It does not, of course, give us everything we could possibly need. We are not provided with a check-list of the translations of Synge's work, and are thus deprived of an accurate insight into Synge's significance as a world figure. It does not give us the detailed information that could only be provided by a full-dress bibliography of of Synge's works. These are two matters which fall outside its province, and rightly so. This book is not intended to do our work for us, but to direct us to work that is yet to be done. It is less a conclusive summary than a compulsive summons, and it is to be hoped that when the time for a second edition comes around there will be many more entries reflecting the way in which the first one has directed and assisted us towards the further exploration of an author whose works and personality remain significant, not only to 


\section{Foreword}

the history of Anglo-Irish literature and drama but also to the continuing exploration of the human condition.

University of Victoria

ROBIN SKELTON

British Columbia 


\section{Preface}

In 1971, the J. M. Synge Centennial celebrations showed the wide attention this playwright continues to command. As this bibliography itself demonstrates, studies on Synge are assuming greater proportions with each passing year. The result is an unusually large output of material, which has never been recorded in one full-length authoritative reference work. Most of the existing bibliographies are either incomplete or inaccurate. Some of these inaccuracies, whether in standard bibliographical aids or appended to such works as Maurice Bourgeois' John Millington Synge and the Irish Theatre, have been repeated unchecked in subsequent studies of the dramatist.

The present bibliography, which comprises some 2500 items, has been compiled on the lines shown in the Table of Contents. With articles in periodicals and similar short pieces, I have given page-references whenever possible; in the case of books (those, for example dealing with drama in general, where references to Synge are scattered) I have given only the name of the book. Some reviews of books or play productions were worth including in the articles section. The bibliography is intended to be complete up to the end of 1971, although some later studies have been listed.

Acknowledgements are due to the following libraries for their cooperation and assistance: The University of Lethbridge Library; the British Museum Library; the National Library of Ireland; and the Newspaper Library at Colindale. I am also grateful to Miss Bea Ramtej for her immense help.

E. H. MIKHAIL

Lethbridge, Canada 